\title{
Imágenes para sacralizar, controlar y someter. La pintura y el discurso matrimonial tridentino en el Nuevo Reino de Granada. Siglo XVII*
}

\section{Resumen}

Este artículo estudia el discurso matrimonial inscrito en la pintura colonial neogranadina del siglo XVII y los usos que se le dieron en el contexto pos-tridentino. El estudio se efectúa a través del análisis iconográfico de tres pinturas coloniales centradas en el tema de los Desposorios de María y San José, examinadas en relación con fuentes documentales y textos morales impresos en los siglos XVII y XVIII. La investigación se enmarca en el espacio geográfico del Nuevo Reino de Granada, lugar de difusión del discurso visual protagonista de este texto. Como resultado, el análisis permitió establecer que la imagen colonial de los desposorios de la Virgen y San José funcionó en la Nueva Granada como un mecanismo de difusión del modelo matrimonial desarrollado en el Concilio de Trento. Dicho ejemplo buscaba, como fin último, controlar tanto las actitudes como la sexualidad de los contrayentes.

\section{Palabras clave}

Tesauro: historia latinoamericana, matrimonio, pintura, artes visuales, Iglesia, cristianismo, iconografía.

Referencia bibliográfica para citar este artículo: Cruz Medina, Juan Pablo. "Imágenes para sacralizar, controlar y someter. La pintura y el discurso matrimonial tridentino en el Nuevo Reino de Granada. Siglo XVII". Anuario de Historia Regional y de las Fronteras 24.1 (2019): 57-82.

Juan Pablo Cruz Medina: magíster en Historia de la Universidad de los Andes, Colombia, e historiador de la Pontificia Universidad Javeriana, Colombia. Sus investigaciones se han centrado principalmente en la conquista de América, la pintura colonial neogranadina y los procesos culturales relacionados con esta. Actualmente desarrolla el proyecto de organización, catalogación e investigación del archivo de las Legaciones de Colombia Ante la Santa Sede con el Archivo General de la Nación. Código ORCID: http:// orcid.org/0000-0003-3189-6594. Correo electrónico: cruzmedjp@gmail.com.

\footnotetext{
* Este artículo surge como parte de la investigación desarrollada para optar por el título de Maestría en Historia en la Universidad de Los Andes (Bogotá). La tesis titulada "Sujetos Controlados, Relaciones Familiares Sometidas. El discurso en la pintura de la Sagrada Familia, Santafé siglo XVII" fue sustentada en el año 2011 y apoyada económicamente por COLCIENCIAS en el marco del plan de fortalecimiento institucional de la Fundación Erigaie
} 


\title{
Images to Sacralise, Control and Subdue. The Painting and the Tridentine Matrimonial Discourse in the New Kingdom of Granada. Seventeenth Century
}

\begin{abstract}
This paper studies the matrimonial discourse inscribed in neo-granadian colonial painting of the seventeenth century and the uses that were given to it in the posttridentine context. The study is carried out by means of the iconographic analysis of three colonial paintings centered on the subject of the Marriage of the Virgin, examined regarding documentary sources and moral texts printed in the seventeenth and eighteenth centuries. The research is framed within the geographical space of the New Kingdom of Granada, a place of dissemination of the visual discourse, which is the focus of this text. As a result, the analysis enabled to establish that the colonial depicting of the Marriage of the Virgin functioned in New Granada as a disseminating mechanism of the marriage model developed in the Council of Trento. Such an example sought, as the ultimate goal, to control both the attitudes and the sexuality of the contracting parties.
\end{abstract}

Keywords

Thesaurus: Latin American history, Marriage, Painting, Visual Arts, Church, Christianity, Iconography.

\section{Imagens para sacralizar, controlar e subjugar. A pintura e o discurso matrimonial tridentino no Novo Reino de Granada. Século XVII}

\section{Resumo}

Este artigo estuda o discurso matrimonial inscrito na pintura colonial neogranadiana do século XVII e os usos que foram-lhe dados no contexto póstridentino. O estudo realizado através da análise iconográfica de três pinturas coloniais centradas no tema da O Casamento da Virgem Maria com São José, examinado em relação a fontes documentais e textos morais impressos nos séculos XVII e XVIII. A pesquisa é enquadrada dentro do espaço geográfico do Novo Reino do Granada, local de divulgação do discurso visual protagonista deste texto. Como resultado, a análise permitiu estabelecer que a imagem colonial do Casamento da Virgem Maria com São José funcionou em Nova Granada como um mecanismo de difusão do modelo matrimonial desenvolvido no Concílio de Trento. Este exemplo procurou, como objetivo final, controlar tanto as atitudes como a sexualidade das partes contraentes.

\section{Palavras-chave}

Tesauro: história da América Latina, casamento, pintura, artes visuais, Igreja, cristianismo, iconografia. 


\section{Introducción}

En la última década diferentes estudios han centrado su atención en la función cumplida por los discursos visuales en la Nueva Granada colonial. Los análisis han arrojado algunas luces en relación con la materia, destacando de la pintura y la escultura no sólo la clásica función de "libros para analfabetos", relacionada con la evangelización indígena, sino también la existencia de una complejidad discursiva tendiente hacia el control de los sujetos. Por medio de la enseñanza y la demostración de vicios y virtudes, las imágenes brindaban ejemplos a la feligresía induciendo con ello modos de comportamiento adecuados a las normas tanto de la Iglesia como de la monarquía. ${ }^{1}$ La imagen se convirtió así en una materialización del pensamiento político y religioso imperante en los siglos XVI, XVII y XVIII.

Si aplicamos esto a la imagen de los "desposorios de la Virgen y san José", motivo iconográfico bastante difundido no sólo en la Nueva Granada del siglo XVII sino en el resto de la américa española, podríamos aseverar que a partir de la imagen es factible reconstruir también parte del "lugar de producción" que le dio vida. Es decir, que la pintura nos puede llevar a reconstruir la lógica matrimonial de la época, centro de la representación pictórica, en tanto que una es reflejo de la otra.

Ahora bien, ¿Qué nos dicen las imágenes de los "desposorios de la virgen y san José" producidas en la nueva granada en el siglo XVII acerca del discurso matrimonial implantado en estos territorios? Para responder a esta pregunta, centro del presente artículo, utilizaré como fuente tres pinturas producidas en el siglo XVII neogranadino cuyo tema son los “desposorios de la virgen y San José", modelo icónico utilizado por la Iglesia para llevar a los fieles la idea del matrimonio. La escogencia de estas pinturas radica en que su iconografía presenta la misma línea compositiva observable en las diferentes representaciones que de este tema se hicieron en la Nueva Granada. Esto queda demostrado al observar las pinturas que de los desposorios existen en ciudades como Tunja, Popayán, o Cali, las cuales, salvo algunas variaciones mínimas, respetan el modelo presente en las pinturas santafereñas aquí utilizadas. $^{2}$

\footnotetext{
"Vale la pena recordar que la imagen en el siglo XVII no se consideraba un "objeto artístico" sino un instrumento retórico dirigido a convencer a los fieles de un discurso determinado. Para esto la imagen debía cumplir con los tres preceptos de la retórica clásica: deleitar, conmover y persuadir. Deleitaba por medio del ornato y los colores; conmovía a partir de la expresión de escenas o sentimientos cuya finalidad era la de impresionar al público; y persuadía a partir de la enseñanza de vicios y virtudes que, acompañada de la afectación de los sentidos, debía mover a los fieles hacia la virtud. Cf. Jaime Humberto Borja, Pintura y cultura barroca en la Nueva Granada. Los discursos sobre el cuerpo (Bogotá: Fundación Gilberto Alzate Avendaño-Alcaldía Mayor de Bogotá) 38-43.

${ }^{2}$ El modelo compositivo de las pinturas de los “Desposorios de la virgen y San José” parte de la representación de María y José, acompañados por un grupo de hombres y mujeres, en el momento en que su unión es bendecida por el sacerdote. Esta fórmula se repite no solo en las pinturas neogranadinas, sino también en las existentes en contextos como los del Virreinato del Perú y la Nueva España. Imágenes atribuidas a los novohispanos Cristóbal de Villalpando y José Juárez, o a los círculos cuzqueños, son muestra de ello, evidenciando el uso de una composición iconográfica que ya era común en Europa. Rafael Sanzio ya había utilizado este modelo para realizar el fresco de los Desposorios de Milán (1504), y posteriormente pintores españoles del Barroco como Francisco Ribalta (1565-1628) y Juan de Valdés Leal (1622-1690), siguieron
} 
A partir del análisis de dichas imágenes pretendo reconstruir el discurso impuesto por la Iglesia y la monarquía, no sólo en torno al sacramento matrimonial, sino también en lo concerniente a la sexualidad y las relaciones de poder entre el hombre y la mujer, dos aspectos asociados a vinculo marital. La imagen de los Desposorios será observada entonces como un canal utilizado por la Iglesia para comunicar las normas trasladadas desde Europa y convertidas en regla de vida dentro del contexto americano. La historia que buscamos relatar aquí no es por ende la de una práctica, sino la de un discurso emanado de la autoridad -la Iglesia y la Monarquía-, y asentado sobre la pretensión de forjar una sociedad cuya célula debía ser la familia Cristiana.

El matrimonio, como núcleo de dicha célula, estuvo fuertemente regulado a partir de las pautas dispuestas por el Concilio de Trento (1545-1563), ${ }^{3}$ reforzadas posteriormente por disposiciones legales, así como por los discursos inscritos en la narrativa moral del siglo XVII que circuló en la Nueva Granada. La imagen, sumada a sermones y libros morales, transmitió a las nacientes sociedades la idea de un matrimonio que, como sacramento, era inquebrantable y conducente hacia el control de la sexualidad y el sometimiento de lo femenino, sustentado en el rechazo y el sometimiento teológico de la mujer.

La pintura, tomada aquí como fuente privilegiada, nos permite evaluar el modelo de familia impuesto por la Corona Española en la Nueva Granada del siglo XVII, evidenciando que la idea de matrimonio expresada desde el orden eclesiástico, se aunaba a un esquema de control y sometimiento de los sujetos coloniales. ${ }^{4}$ La idea

el esquema en sus representaciones de los desposorios. Al respecto puede verse: Luisa Elena Alcalá y Jonathan Brown eds. Pintura en Hispanoamérica 1550-1820 (Madrid: Ediciones el Viso-Fondo Cultural Banamex, 2014).

${ }^{3}$ Como respuesta a las críticas de la Reforma Protestante el Papa de la Iglesia Católica Paulo III citó un concilio ecuménico desarrollado en la ciudad italiana de Trento entre 1545 y 1563 . En este se rebatieron una a una las críticas de los protestantes y se reafirmaron diferentes dogmas y posturas eclesiásticas, dando vida así a la llamada Contrarreforma. El concilio en líneas generales sentó una férrea posición eclesiástica, dominada no sólo por la ortodoxia, sino por la resolución de obligar en la sociedad su obediencia a los mandatos eclesiásticos en medio de un fortalecimiento del temor a Dios. La imagen, en medio de esto, sería confirmada como un mecanismo para acercarse a Dios, postura que rebatía la postura iconoclasta protestante, y ratificaba todo aquello señalado en concilios anteriores -Nicea, especialmente- en relación con la imagen y su uso. Finalmente, por cedula real del 12 de julio de 1564 el Concilio de Trento entraría en vigencia dentro del Imperio Español, incluyendo los reinos ultramarinos americanos. Cf. Marialba Pastor, Cuerpos Sociales, Cuerpos Sacrificiales (México: FCE, 2004) 47; Ramón Mujica Pinilla, La imagen transgredida. Ensayos de iconografia peruana y sus políticas de representación simbólica (Lima: Fondo Editorial del Congreso del Perú, 2016) 477; y Novísima recopilación de las Leyes de España, mandada formar por el señor don Carlos IV. Tomo I, Libro 1 (Madrid: S.e. 1805) 5.

${ }^{4}$ Para los fines propios del presente artículo defino el "Sujeto" Colonial como aquella persona que se encuentra sujetada por la política, la ley y el control propio de la Monarquía Hispánica de los siglos XVI, XVII y XVIII. En este sentido aplico al colonizado por la Corona Española la categoría de sujeto, leyendo al colonizador como emisor del discurso que sujeta. Aquí me distancio entonces de lo planteado por Rolena Adorno quien sostiene que la categoría de "Sujeto Colonial" cobija tanto el colonizador como al colonizado, perspectiva que desde una preocupación meramente discursiva pareciese no tener tanto sentido. Cf. Rolena Adorno, "El sujeto colonial y la construcción cultural de la alteridad", Revista de Crítica literaria latinoamericana 28 (1988): 55-57. 
es entonces analizar la familia no desde las prácticas -aspecto ampliamente trabajado${ }^{5}$ sino desde el discurso que pretendía regularlas. Este enfoque nos permite develar otros matices del periodo colonial y las sociedades que aquí se establecieron, dando cuenta así de muchos de los imaginarios que aun hoy configuran nuestros conceptos en relación con la familia y las relaciones de pareja.

\section{Una imagen para Controlar}

Uno de los aspectos más destacados dentro del discurso visual centrado en el matrimonio que se produjo en la Nueva Granada del siglo XVII fue sin duda el del control de la sexualidad. La importancia que la Iglesia le dio a esta cuestión derivaba del clima social encontrado por la monarquía en los territorios de ultramar. Tras el encuentro de las llamadas "indias occidentales" los peninsulares leyeron la realidad amerindia como un ethos dominado por el desorden sexual y el relajamiento de las costumbres, prácticas asociadas a la falta de religión. Esta visión, obtenida a través de una lente dominada por los ideales cristianos occidentales, ${ }^{6}$ demandaba un fuerte accionar por parte de la Iglesia para controlar la sexualidad indígena, lo cual debía asegurar la construcción de un nuevo orden social.

En paralelo a esto, el reforzamiento de los valores cristianos en aquellos que migraban hacia América se convirtió rápidamente en una necesidad tan importante como la misma evangelización del indígena. ${ }^{7}$ De hecho, la labor evangelizadora en la Nueva Granada halló como principal tropiezo el relajamiento de las costumbres de los peninsulares, quienes tras su llegada a América se entregaron a las borracheras y el amancebamiento propio de los indígenas. Así lo hace saber en 1580 el licenciado Pedro Zorrilla, oidor de Santafé de Bogotá, quien en carta al rey señalaba que no sólo "los indios están tan ignorantes en la fe como al principio", sino que a su vez los españoles eran constantemente sorprendidos en borracheras y trato sexual con

\footnotetext{
${ }^{5}$ Cabe señalar aquí especialmente los trabajos realizados para el caso de Colombia por Pablo Rodríguez Jiménez quien ha dedicado varias de sus investigaciones a la historia de la familia y sus prácticas. Véase: Pablo Rodríguez, Sentimientos y vida familiar en el Nuevo Reino de Granada siglo XVIII (Bogotá: Ariel, 1997) y Pablo Rodríguez, ed. La familia en Iberoamérica: 1550-1980 (Bogotá: Convenio Andrés Bello, 2004).

${ }^{6}$ Siguiendo a Rolena Adorno la visión traída por los peninsulares a América estaba anclada a los ideales de una sociedad hispana dominada por lo masculino, así como por los ideales caballerescos y cristianos. La alteridad fue entonces leída a partir de estos principios, lo cual derivó en la construcción de un modelo social en el cual la instrucción moral cristiana, patriarcal y caballeresca sería predominante. Cf. Rolena Adorno, "The dipiction of self and other in Colonial Perú", Art Journal 49. 2 (1990): 112.

${ }^{7}$ En el caso del indígena, siguiendo lo expresado por el historiador chileno Eduardo Valenzuela, la evangelización se desarrolló en tres etapas: 1) El Kerigma (destrucción de ídolos); 2) la Catequesis (enseñanza de los principios básicos del cristianismo) y 3) La homilética (introducción del indígena ya cristianizado dentro del modelo de "vida en policía" regido por la norma cristiana. Siguiendo esta propuesta podríamos decir que el discurso propio de la imagen de los desposorios aplica a la segunda y tercera etapa del proceso, es decir que se dirige hacia la explicación del sacramento (Catequesis) y la construcción de un modelo de vida en pareja regida por la Iglesia (Homilética). En el caso de los peninsulares migrados a América la labor gestada a partir de la imagen de los desposorios tendía a reforzar el valor- ya aprendidodel matrimonio y el control de la sexualidad. Cf. Eduardo Valenzuela, "Kerigma: preguntas teóricas en torno a la primera evangelización de América (Antillas, 1510-Nueva España 1524)”, Historia Crítica 58 (2015): 13-32.
} 
indígenas. ${ }^{8}$ La crítica al proceso evangelizador neogranadino, evidente en la misiva del oidor, no era para nada un caso aislado en la época. Como lo ha evidenciado Mercedes López, las referencias a borracheras, amancebamientos y trato sexual por la fuerza entre españoles e indígenas, son muy comunes en las últimas décadas del XVI neogranadino. ${ }^{9}$

La solución hallada por la Iglesia para apaciguar el clima sexual desatado en América fue el fortalecimiento de la evangelización a partir del uso de mecanismos como el sermón y la imagen, dos instrumentos fomentados y fortalecidos por las disposiciones del Concilio de Trento (1545-1563). ${ }^{10}$ El discurso visual del matrimonio, proyectado a partir de la iconografía de los Desposorios de la Virgen y San José, adquirió entonces la función de "maestro de vida", en tanto que debía apoyar el control de la sexualidad a partir del modelo de castidad que reposaba sobre las figuras de San José y la Virgen María.

La aparición de la iconografía de los desposorios, en la Nueva Granada estuvo vinculada, por lo tanto, a la necesidad de poner freno a las libertades sexuales que los españoles habían encontrado en el Nuevo Mundo. Frente a esto la Iglesia tenía una posición clara: imponer modelos que controlaran a los sujetos restringiendo -al menos en teoría- su accionar. La libertad según la lógica eclesiástica, tal como lo había señalado Anselmo de Canterbury en el siglo XII, no era tener la capacidad de hacer lo que se quiere, sino de "hacer lo que se debe". ${ }^{11}$ Bajo esta premisa la Iglesia definió muy bien las reglas de ese "hacer", aspecto que en el caso de la sexualidad se ponía de manifiesto en las representaciones de los Desposorios de la Virgen y San José.

Un ejemplo de esto lo podemos encontrar en los Desposorios de la virgen y san José pintados por Baltasar de Figueroa en el siglo XVII (Imagen 1). La imagen se compone de nueve figuras dispuestas en línea horizontal y una inscrita en la esquina inferior derecha de la composición. En el centro se encuentra María y José, quienes dirigen la mirada hacia sus manos que permanecen unidas bajo la mano del sacerdote.

\footnotetext{
${ }^{8}$ Citado en: Juan Manuel Pacheco, Los Jesuitas en Colombia, Tomo 1: 1567-1654 (Bogotá: San Juan Eudes, 1959) 42.

${ }^{9}$ Mercedes López, "Las primeras experiencias cristianas en el Nuevo Reino de Granada: Iglesia indiana y cristianismo indígena", Historia del Cristianismo en Colombia, ed. Ana María Bidegain (Bogotá: Taurus, 2004) 23-42.

${ }^{10}$ Cabe señalar aquí que, aunque Trento fortaleció el valor de la imagen en relación a su poder para mover hacia la piedad y enseñar los diferentes aspectos que componían el discurso cristiano, es claro que esta decisión conciliar solo ratificó una antigua política eclesiástica criticada por reformadores como Martín Lutero y Juan Calvino. La historia del uso de la imagen como catalizadora del fervor religioso se remonta hasta el siglo VIII, cuando en el Concilio de Nicea la Iglesia implementó sendas regulaciones para el uso de las imágenes en medio de la controversia iconoclasta. Durante los siglos siguientes, la Iglesia, Concilio tras Concilio, enmendó y amplió sus disposiciones frente a la imagen, aspecto que se sumaba a los diferentes usos que se le daban a esta en medio de las luchas por la defensa de la cristiandad. El concilio de Trento, en este sentido, solo ajusta y fortalece la política eclesiástica, dando forma a un nuevo ímpetu en relación al uso del discurso visual. Al respecto puede verse: Janeth Rodríguez Nobrega, Las imágenes expurgadas. Censura del arte religioso en el periodo colonial (León: Universidad de León, 2008) 17-36.

${ }^{11}$ Felipe Castañeda, “CCómo pensar la libertad a finales del siglo XI? El caso de Anselmo de Canterbury”. Historia Crítica 18 (1999): 101-117.
} 
Imagen 1: Desposorio de la Virgen y San José Baltasar de Figueroa (Atribuido), siglo XVII.

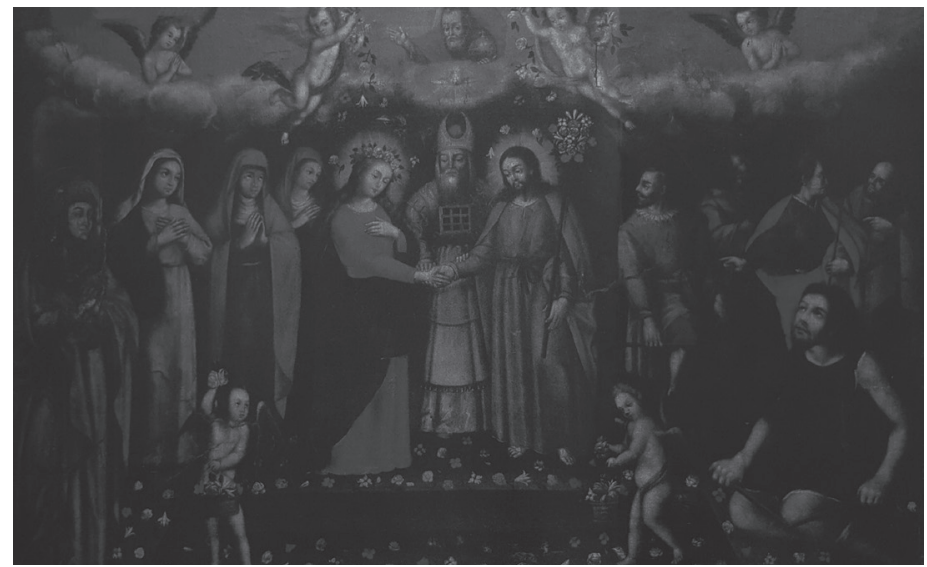

Fuente: Colección Museo Casa Marqués de San Jorge (Bogotá).

La composición escogida por Figueroa, retomada muy seguramente de un grabado, ${ }^{12}$ incorpora dentro de la pintura tres de las historias narradas en los evangelios apócrifos en relación con el tema de los desposorios. La primera es la de la escogencia de José como esposo de la Virgen, representada en la vara florida que porta el santo, así como por la figura que, ubicada en la esquina inferior derecha, rompe una vara con su pierna. Ambos símbolos encarnan el momento milagroso en el que florece el cayado de José, siendo este escogido como compañero de María. ${ }^{13}$

\footnotetext{
${ }^{12}$ El grabado fue sin lugar a duda la fuente más importante para el desarrollo de imágenes tanto en Europa como en el nuevo mundo. Las llamadas "estampas" podían viajar sueltas o en libros, acompañando a los frailes y religiosos que se embarcaban hacia los nuevos territorios. Sabemos, por ejemplo -siguiendo lo anotado por el historiador peruano Ramón Mujica que entre 1571 y 1576 se enviaron de Amberes a España unos 60.000 libros ilustrados con grabados, muchos de los cuales luego fueron enviados a América. Para el caso de la Nueva Granada sabemos, por ejemplo, que existía un amplio comercio de estampas que ingresaban por Cartagena y se diseminaban por todo el territorio. En el caso de los "Desposorios de la Virgen y San José" circularon los grabados hechos por Alberto Durero, Adam Bolswert y Adriaen Collaert. Cabe señalar que, aunque estos grabados sirvieron para difundir la iconografía tridentina, no se copiaban siempre de forma literal por parte de los pintores americanos. El pintor novohispano Juan Correa (Ca. 1646 -1716), por ejemplo, introdujo algunas variaciones frente a los grabados que venían de Europa, tales como el despliegue de flores y la inclusión de un ramo de azucenas como atributo de María para resaltar su virginidad. Cf. Ramón Mujica Pinilla, La imagen transgredida 19; María Cristina Pérez, Circulación y apropiación de imágenes religiosas en el Nuevo Reino de Granada, siglos XVI-XVIII (Bogotá: Uniandes, 2016) 13-18 y Elisa Vargas Lugo y José Guadalupe Victoria, (eds) Juan Correa, su vida y su obra. Repertorio Pictórico, Tomo IV (México: UNAM, 1994) 81.
}

${ }^{13}$ Siguiendo la tradición contenida en los evangelios apócrifos, la elección de José como esposo de María fue realizada a partir de un acto prodigioso. El sumo sacerdote reunió a todos los varones de la casa de David señalando que aquel cuya vara floreciese se casaría con María. El sacerdote y moralista español Alonso de Villegas (1533-1603) recordaba así la historia en su Flos Sanctorum -una de las compilaciones hagiográficas más difundidas en la américa española-: Pidio el sumo sacerdote que todos los varones por casar del linaje de David, de donde ella [María] descendía, se juntasen en el templo un dia señalado, a donde cada uno tomasse una vara en la mano, estando juntos, y que aquel cuya vara floreciesse casasse con esta señora. Todo esto se hizo asi y la vara de san Joseph floreció y añaden algunos que baxo una paloma de lo alto que se asentó en la vara florida. Fueron luego desposados la Virgen y san Joseph, y fue entre ellos verdadero matrimonio". Alonso de Villegas, Flos Sanctorum y Historia General en que se escribe la vida de la Virgen Sacratissima madre de Dios y Señora nuestra y la de los santos antiguos que fueron antes de la venida de nuestro Salvador al Mundo (Barcelona: Imprenta de Pablo Nadal y Pedro Escuder, 1748) 33. 
La segunda historia es la del compromiso de José y María, momento en el cual el futuro padre putativo de Jesús visita a María en su casa para pactar el matrimonio. En esta ocasión, siguiendo el texto apócrifo, tanto la Virgen como José eran acompañados por mujeres y hombres -respectivamente- que servían como testigos del compromiso. ${ }^{14}$ Finalmente, está el momento del matrimonio mismo, representado en el centro de la pintura. Aquí se observa a María y José bendecidos por el sacerdote, quien impone su mano sobre las de los contrayentes para sacralizar la unión.

Al observar la pintura atribuida a Baltasar de Figueroa, llaman la atención tres elementos relacionados directamente con la contención de la sexualidad: el primero de ellos es la vara florida que porta San José. Este símbolo resalta la castidad del santo, presentando de paso dicho atributo como requisito para el matrimonio. La vara simboliza desde las tradiciones antiguas el poder viril del varón, así como el don de mando asociado a este. Al ser mezclado con las flores, la representación de este objeto no sólo da cuenta del milagro relacionado con la elección de José como marido de la Virgen, sino también de la castidad que se debe guardar en relación con la virilidad. De hecho, uno de los tópicos que se repite en las hagiografías propias del siglo XVII es el de la castidad perpetua asociada a San José. Alonso de Villegas, por ejemplo, dedica varias páginas de su "vida de la Virgen", a demostrar que tanto san José, como María, llegaron castos al matrimonio, estado que mantuvieron aun después de sacralizada la unión. ${ }^{15}$

El segundo elemento que evidencia el modelo de comportamiento sexual que buscaba implantar la Iglesia en la Nueva Granada, es la figura masculina que se ubica en la parte inferior derecha de la pintura. El hombre, dirigiendo la mirada hacia el cielo mientras rompe con la rodilla una vara, personifica la renuncia a la Virgen María, con quien -siguiendo las narraciones apócrifas- se pretendía casar. ${ }^{16}$ Este gesto, incluido dentro de la representación de los desposorios desde el siglo XV, ${ }^{17}$ servía para reforzar el tema del respeto al matrimonio y al compromiso de la pareja.

\footnotetext{
${ }^{14}$ La historia del matrimonio de José y María es narrada en textos apócrifos de los primeros siglos del cristianismo tales como el "Evangelio de la Natividad de María" y las versiones Copta y Árabe de la "Historia de José el Carpintero". Cf. Aurelio de Santos Otero, Los Evangelios Apócrifos (Madrid: Biblioteca de Autores Cristianos, 1956) 258-274 y 358-378.

${ }^{15}$ En su hagiografía Villegas cita los escritos de diversos santos y padres de la Iglesia (San Agustín, San Gerónimo, San Ruperto Abad, san Marcos, San Mateo), así como los evangelios mismos, para demostrar que san José era virgen a igual que María. Su tesis, sustentada en la autoridad de textos considerados como fuentes de verdad, reforzaba la idea de que la castidad era superior al matrimonio. Narraciones como estas apoyaban el relato visual inscrito en la pintura promoviendo una contención de la sexualidad a partir de los modelos expresados por María y San José. Cf. De Villegas, Flos Sanctorum 34-36.

${ }^{16}$ Recordemos que, siguiendo la narración hagiográfica, la escogencia de José se hizo dentro de un grupo de varones pertenecientes a la tribu de Judá, a partir de una señal, el florecimiento de su cayado. Los demás aspirantes tuvieron que aceptar que José fuera el esposo de María, lo cual se representa en la pintura a través del hombre que rompe con su rodilla la vara "estéril". Cf. Miguel Pérez, La vida y excelencias y Miraglos (Sic) de la Sacratissima Virgen María nuestra señora (Sevilla: Imprenta de Juan Varela de Salamanca, 1525) 9v y Hector Schenone, Iconografía del Arte Colonial: Santa María (Buenos Aires: Universidad Católica Argentina, 2008) 149-151.

${ }^{17}$ La figura, incluida como elemento iconográfico por Rafael Sanzio en sus desposorios de 1504, no aparece indicada en los diferentes relatos de los desposorios, ni en los evangelios apócrifos, donde únicamente se señala "el enojo de los rechazados", evidenciado frente al florecimiento de la vara de San José.
} 
El tercer elemento simbólico para destacar dentro de la pintura son las diferentes canastas de flores que acompañan la imagen central. La mujer es representada aquí -a partir del arquetipo de María- como una figura virginal que entrega su sexo al hombre a cambio de la promesa de fecundación de su vientre, aspecto que se expone en la pintura a partir de las canastas llenas de flores, símbolo del vientre femenino fecundado. ${ }^{18}$ El uso de las flores dentro de las representaciones de los desposorios, así como en otras iconografías, aunque no parece ser un rasgo exclusivo de la pintura colonial americana, si puede situarse como un aspecto distintivo de la misma. En el caso de los desposorios el tema de la canasta con flores apareció en el siglo XVII, como atestiguan las estampas realizadas por el grabador flamenco Adriaen Collaert (1555-1623) en las que se observa este elemento, que no aparecía -por ejemplo- en las pinturas que sobre este tema realizó Rafael Sanzio en los albores del siglo XVI.

Las flores no son un aspecto común dentro de la representación europea de los desposorios. En los grabados que sobre el tema realizó Schelte Bolswert (1586-1659) no se observa el uso de las flores, mientras que pinturas cuzqueñas y novohispanas que tomaron como base estos grabados, sí introducen el elemento floral dentro de las representaciones. Esta particularidad, evidente en pinturas neogranadinas, peruanas y novohispanas centradas en el tema de los desposorios, puede indicar la especificidad misma del discurso matrimonial americano: el uso de las flores para hacer referencia a la fecundación, expuesta como único fin del matrimonio.

La pintura atribuida a Figueroa, aparte de presentar la historia apócrifa del matrimonio de José con María, establecía entonces toda una serie de entramados simbólicos dirigidos a exponer un modelo de cuerpo a los neogranadinos, basado en el rechazo de la sexualidad. La contención sexual subrayaba el carácter de "remedio a la concupiscencia" otorgado al sacramento matrimonial desde la Edad Media, ${ }^{19}$ a la vez que controlaba la corporeidad de los sujetos, encausándola dentro de un modelo definido. Pero la imagen no actuaba sola. Dispuesta como apoyo visual, esta servía para tender relaciones entre la iconografía y los discursos propagados a partir de sermones, panegíricos y la literatura moral de la época. Un ejemplo de esto

Al parecer este símbolo es una invención iconográfica propia del cuatroccento, incluida posteriormente en el grabado de Ioan Stradanus y Adrian Collaert (Ca. 1585) que serviría como base para la mayoría de las representaciones de los "desposorios" desarrolladas en América. Cf. Schenone, Iconografía, 149-151.

${ }^{18}$ Jean Chevalier, Diccionario de los Símbolos (Barcelona: Herder, 1986) 747.

${ }^{19}$ Desde su surgimiento como sacramento en el primer Concilio de Letrán, la discusión en torno al Matrimonio se centró en el hecho de sacralizar la unión carnal, teniendo en cuenta la incertidumbre que esto conllevaba en relación a la sexualidad y su carácter pecaminoso. La idea de la Iglesia con la elevación del matrimonio a la categoría de Sacramento era la de controlar y disciplinar la sexualidad de los sujetos, promoviendo de paso no solo la procreación sino también la composición de una normativa que hiciera legales ciertas uniones e ilegales otras. A partir de esto grandes teólogos y moralistas como San Isidoro de Sevilla ofrecieron una normativa concreta de la unión matrimonial, situándola como freno a la sexualidad. Para la patrística de los siglos IV y V, fundamento de la religiosidad medieval, el matrimonio comportaba "tres bienes" que lo definían como sacramento: era el remedio contra la concupiscencia, aseguraba una ayuda recíproca y garantizaba la perpetuidad de la especie humana. Véase: Jean Gaudemet, El matrimonio en Occidente (Madrid: Taurus, 1993) 118; y James Casey, Historia de la Familia (Madrid: Espasa Calpe, 1990) $138-140$. 
Imágenes para sacralizar, controlar y someter. La pintura y el discurso matrimonial...

lo encontramos en la pluma del canónigo salmantino Francisco de Farfán, quién en sus Tres libros contra el pecado de la simple fornicación, obra publicada en 1585, señala que

el acto sexual se encamina a la procreación y a la posterior educación de los jóvenes, circunstancia que sucede incluso entre los animales. Por tanto, el acto tiene que ser regulado, en este caso mediante el matrimonio. ${ }^{20}$

Escritos como el de Farfán, sumados al uso de la imagen daban forma a una política eclesiástica que en relación con la sexualidad y el matrimonio establecía unas pautas claras. La idea convertía al cuerpo en un enemigo, frente al cual, los fieles debían -siguiendo las palabras de San Alfonso de Ligorio- alimentar "un odio sano e implacable negando las satisfacciones que nos pide". ${ }^{21}$ El modelo, aplicado a quienes conforman la pareja, debía persuadir a los fieles hacia la modificación de sus conductas sexuales, creándoles -al menos en teoría- el hábitus ${ }^{22}$ de la castidad y el repudio de los placeres carnales. En este sentido el moralista neogranadino Juan Bautista del Toro en su Secular Religioso es tajante:

Los grandes males del mundo son la concupiscencia de la carne, la codicia de los ojos y la soberbia de la vida. Porque el mundo tiene hermosuras y tiene deleytes carnales. Ves ay la concupicencia de la carne que debe ser aborrecida por todo christiano. ${ }^{23}$

Frente a dicha "concupiscencia de la carne", es que se instituye el matrimonio. La unión bendecida por Dios configuraba en la pareja el deber de "aborrecer los placeres carnales", controlando su sexualidad de tal forma que la únicamente buscara el sexo con fines procreativos. Los placeres hallados por los españoles en la Nueva Granada serán así objeto de control por parte de una Iglesia que siguiendo los patrones tridentinos utilizará la imagen para transformar conductas. Todo esto se suma al uso y enseñanza de otras prácticas enmarcadas dentro de la visión moralista y prohibicionista derivada de la Contrarreforma. La Confesión, la oración diaria o la asistencia a misa hacían que los hombres se mantuvieran fieles a la doctrina: a partir de esto se pretendía moralizar la sexualidad produciendo en el individuo un profundo sentimiento de la falta, la culpa y el miedo. ${ }^{24}$

\footnotetext{
${ }^{20}$ Francisco de Farfán citado en: Stuart B. Schwartz, "Pecar en las colonias. Mentalidades populares, Inquisición y actitudes hacia la fornicación simple en España, Portugal y las colonias americanas", Cuadernos de Historia Moderna 18: (1997) 54.

${ }^{21}$ Alain Corbin, ed. Historia del Cuerpo, Vol. 1 "Del Renacimiento al siglo de las Luces" (Madrid: Taurus, 2005) 75 .

${ }^{22}$ Defino hábitus siguiendo a Pierre Bourdieu como todas aquellas formas de ser adquiridas y convertidas en "estructurantes" o mecánicas a partir de su interiorización. Para los católicos un hábitus puede ser persignarse al ingresar a un templo, acción adquirida y convertida por repetición en acto reflejo. Al respecto véase: Pierre Bourdieu, La Distinción. Criterio y bases sociales del gusto (México: Taurus, 2012) 199-263. ${ }^{23}$ Juan Bautista del Toro, El Secular Religioso, 1 ${ }^{\text {a }}$. Ed. 1712 (Madrid: Imprenta de Francisco del Hierro, 1721) 19.

${ }^{24}$ André Burgiere, Historia de la Familia, Volumen II: "El impacto de la Modernidad" (Madrid: Alianza, 1988) 146.
} 
El juicio de las acciones terrenales y el temor a la muerte, al demonio, al infierno y a la condenación eran "sembrados en los sujetos como herramienta para controlar sus actitudes, para forjar una asimilación de los discursos". ${ }^{25}$ A partir de este lugar de experiencia - propio de los sujetos- la Iglesia podía manipular a la sociedad neogranadina, dirigiéndola hacia la adopción de prácticas como la castidad o el respeto al matrimonio, ambas difundidas a partir de la conjunción entre imagen y sermón.

\section{Una imagen para someter}

Dentro del contexto de la Nueva Granada del siglo XVII el amor no era el eslabón que unía a una pareja. De hecho, este sentimiento no existe más que como definición de la relación que debía gestarse entre Dios y los hombres. El amor, tal y como hoy lo conocemos, no es sino una construcción heredada del romanticismo propio de los siglos XVIII y XIX, contexto en el cual se planteó una idealización de la relación de pareja en correspondencia con la expresión de cariño dispuesta por cada una de las partes. ${ }^{26}$ La Iglesia del siglo XVII veía al amor, cuando este era distinto al emanado de la relación con Dios, como algo pecaminoso que debía ser suprimido de la cotidianidad de la pareja. ${ }^{27}$

La Iglesia, en este sentido, situó el matrimonio como un contrato mediado por la clase social, el estatus profesional o la nobleza e hidalguía de los contrayentes. ${ }^{28}$ Dicho contrato estaba tan exento de amor, que muchas veces los novios no se conocían y eran sus padres quienes arreglaban el acuerdo en presencia de un sacerdote. ${ }^{29}$ Esto

\footnotetext{
${ }^{25}$ Pastor, Cuerpos sociales 47.

${ }^{26}$ Jean Luis Flandrin, Orígenes de la Familia Moderna (Barcelona: Crítica, 1979) 217.

${ }^{27}$ En el periodo colonial rara vez es utilizada la palabra amor por fuera de la relación que deben tener los hombres con Dios. La ley mosaica señalaba "amarás a Dios sobre todas las cosas", lo cual ubicaba al sentimiento amoroso al margen de toda relación de pareja. Como señala Teresa Pereira, "Existía una convicción de que el amor era una pasión irracional y destructiva, un impulso irresistible de los sentidos, situación que se daba generalmente fuera del matrimonio. En cambio, el sentimiento conyugal significaba respeto, dilectio, mezcla de ternura y amistad”. El amor sin límites sugería desenfreno sexual y locura, razón por la cual era visto con desconfianza, aun cuando la larga tradición de la literatura caballeresca medieval lo había ponderado como ingrediente central de sus relatos. Aunque esta postura se matizará en el Concilio de Trento a partir de la búsqueda de una unión marital basada en una mezcla de amor y amistad, el amor desenfrenado seguirá siendo censurado y leído como una enfermedad. Véase: Teresa Pereira Larraín, Afectos e Intimidades. El mundo familiar en los siglos XVII, XVIII y XIX (Santiago de Chile: Universidad Católica de Chile, 2007) 142-143 y 163; y para el tema del amor en la novela caballeresca puede verse: Jean Markale, El amor cortés o la pareja infernal (Barcelona: Medievalia, 1998).

${ }^{28}$ Burgiere, Historia de la Familia 91-92.

${ }^{29}$ El matrimonio en el periodo colonial involucraba en la mayoría de las ocasiones a los padres y familiares de la pareja. Los padres buscaban a través de la unión de sus hijos mantener el prestigio familiar o acrecentarlo, a partir de alianzas que convertían al sacramento matrimonial en un proceso colectivo. No obstante, existieron uniones exentas de la presión o el acuerdo familiar, y aun cuando los intereses materiales mediaban en las uniones, la Iglesia buscó respetar la voluntad de los contrayentes. La injerencia de los padres y la familia en las uniones maritales se haría mucho más fuerte en el siglo XVIII, debido a las disposiciones reales que obligaban a los futuros esposos a contar con la aprobación de sus padres para hacer efectiva la unión. La Real Pragmática de 23 de marzo de 1776, dictada por Carlos III, estableció en este sentido que los hijos de familia menores de veinticinco años debían presentar ante la Iglesia un permiso de sus padres. La medida buscaba poner freno a matrimonios no consensuados o que posibilitaran un incremento de las mezclas raciales. Véase: Pereira, Afectos e intimidades 65-68.
} 
se ubicaba dentro de una lógica heredada del mundo medieval, en la cual el padre o pariente más próximo entregaba la esposa al futuro marido en calidad de donación (de feudo), a cambio de que esté le brindara su protección. ${ }^{30}$ Como consecuencia de esto la familia de la mujer debía pagar al hombre "una dote" por su protección, cuantía que podía ser sufragada en dinero o bienes. ${ }^{31}$

La práctica de estas tradiciones, trasladadas a América como ejes rectores de la sociedad, darían forma a una relación marital definida a partir de modelos comportamentales dirigidos tanto al hombre como a la mujer. Puntualizar los roles que cada componente de la pareja debía cumplir, se convirtió así en otra de las necesidades de la Iglesia neogranadina del siglo XVII, en medio de la construcción de un modelo social que -al menos en el discurso- se comportaba como una exacerbación del machismo y la masculinidad.

La iconografía de los Desposorios se presenta aquí como un canal para la difusión de ese discurso, así como para la transmisión de los modelos de mujer y hombre que debían integrar la pareja cristiana, tal como lo podemos observar en los "Desposorios de la virgen y san José" atribuidos a Gregorio Vásquez de Arce y Ceballos (Imagen 2). La pintura, datada en el siglo XVII, expresa a partir de la corporeidad de sus protagonistas el papel que habrá de representar cada uno en la relación de pareja.

Detengámonos en primera instancia en la imagen de la Virgen, ubicada al lado derecho de la pintura. La figura femenina no sólo inclina la cabeza, sino que a la vez expone evidentemente su vientre, ${ }^{32}$ en el cual lleva a Jesús. La expresión de su rostro demuestra sumisión y entrega, siguiendo los cánones propios de la pintura

\footnotetext{
${ }^{30}$ Georges Duby, Historia de la Vida Privada, Vol. 2 "De la Europa Feudal al Renacimiento" (Madrid: Taurus, 1991) 145.

${ }^{31}$ La dote era sin lugar a duda uno de los aspectos centrales dentro de las alianzas matrimoniales del periodo colonial, especialmente las efectuadas en los sectores más privilegiados de la sociedad. Como ha señalado Jorge Gamboa, la dote -compuesta por una cantidad de dinero o bienes entregada al futuro marido por la familia de la novia- se convertía en uno de los puntos centrales de la negociación de un matrimonio, siendo una garantía frente al futuro para aquellas mujeres que iban a contraer nupcias. Cabe señalar que, aunque el uso de la dote deriva de una larga tradición que se remonta al mundo germánico, muchas de las comunidades amerindias tenían tradiciones similares. Como ha señalado Jorge Gamboa, los muiscas, habitantes prehispánicos del altiplano Cundiboyacense, "concertaban los matrimonios discutiendo el pago que haría el novio a los parientes de la esposa. Cuando todos estaban de acuerdo, la mujer era entregada sin más ritos ni dilaciones". En este caso, contrario a la tradición europea, era la familia del novio la que debía pagar a la familia de la novia. Véase: Jorge Gamboa, El precio de un marido. El significado de la dote matrimonial en el Nuevo Reino de Granada. Pamplona. 1570-1650 (Bogotá: ICANH, 2003) 9-13.

${ }^{32}$ El "ofrecimiento del vientre" como símbolo utilizado dentro de la pintura relacionada con el matrimonio fue una idea a menudo replicada, aun por fuera de las representaciones de carácter religioso. Cabe mencionar aquí el caso del "Matrimonio Arnofini”, pintura del holandés Jan Van Eyck fechada en 1434. En ella se representa al mercader Giovanni Arnolfini junto a su esposa Giovanna Cenami, uno al lado del otro tomados de la mano. La mujer recoge parte de su vestido contra el vientre en señal de ofrecimiento, símbolo que se constituye como certificación tanto del matrimonio de la pareja, como de la consumación del mismo. Un análisis de esta pintura puede verse en: Jerome Baschet, La civilización feudal. Europa del año mil a la colonización de América (México: FCE, 2009) 39.
} 
del XVII. Según el tratadista italiano del siglo XVI Vicente Carducho, la sumisión se representa con "La carne húmeda, los ojos inclinados, tardo movimiento, grave y blando, los cabellos llanos y suaves, las acciones graves, recogidas". ${ }^{33}$

Imagen 2: Desposorios de la Virgen y San José Gregorio Vásquez de Arce y Ceballos (Atribuido), siglo XVII.

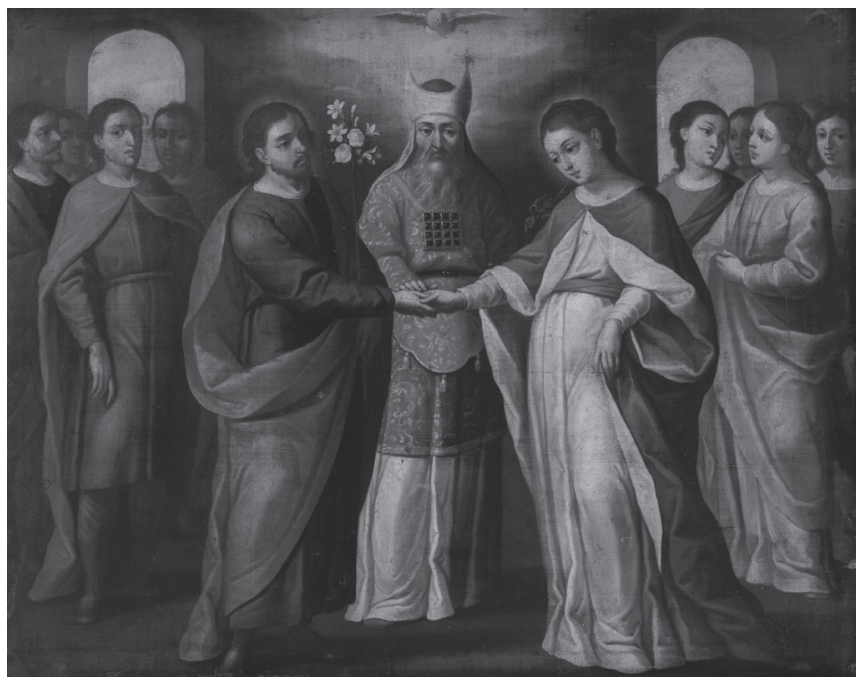

Fuente: Colección Museo Colonial (Bogotá)

La figura de San José, por su parte, se sitúa como opuesta a su contraparte femenina. La vara, símbolo del poder viril y del mando - quién lleva la vara es guía o pastor- acompaña una postura corporal recta en la que la mirada del personaje no se inclina, sino que se dirige directamente hacia la de María. A esta actitud corporal se suma un elemento propio de las representaciones de José en la pintura americana: su juventud. Contrario a la imagen de un hombre viejo difundida a través de los grabados, la pintura contrareformista buscó adecuar la imagen de José al perfil del hombre que se creía debía integrar la pareja cristiana: un hombre joven que representara el vigor y la vitalidad propias de su edad. A partir de ello se resaltaba su papel como guía de la mujer y de la familia misma.

El modelo de sometimiento femenino iba de la mano con la idea de vigilar y controlar a la mujer, en tanto que esta era concebida desde la teología como "corrupta y culpable". La mácula acarreada por la mujer tenía su origen en las narraciones Génesis bíblico, específicamente la que narra el momento en que Eva tienta a Adán con la manzana haciéndolo pecar. La historia veterotestamentaria le impondrá a la mujer no sólo el título de pecadora por excelencia, sino también el yugo que derivaba de dicho título. ${ }^{34}$ El castigo de la mujer como "Pecadora Original" -siguiendo el libro

\footnotetext{
${ }^{33}$ Vicente Carducho, Diálogos de la Pintura. Su Defensa, Origen, esencia, definición, modos y diferencias. (1ed. 1633) (Madrid: Turner, 1979) 401.

${ }^{34}$ Duby, Historia de la Vida Privada 92.
} 
bíblico del Génesis- era doble, por un lado recibía un "castigo divino": Parirás con dolor ; y por otro un castigo humano: "estarás bajo la potestad del hombre y él te dominará". ${ }^{35}$ La idea inscrita en el primer libro bíblico será recogida por el apóstol San Pablo, quien en su carta a Timoteo reiterará el estado de sometimiento al que debe acogerse la mujer:

La mujer déjese instruir en silencio con toda sumisión. No tolero que la mujer enseñe, ni que se tome autoridad sobre el marido, sino que ha de mantenerse sumisa. Pues Adán fue formado el primero, luego Eva. Y no fue Adán quien se dejó engañar, sino Eva, que, seducida, incurrió en la transgresión. ${ }^{36}$

Estas ideas complementadas y fortalecidas por la patrística medieval terminaron definiendo claramente el rol de la mujer frente a su esposo, modelo que sería trasladado a la Nueva Granada y difundido por la Iglesia como parte del proyecto de construcción de una nueva sociedad en la América Española. La imagen de los desposorios se constituirá únicamente como un mecanismo de difusión del antiguo modelo que observaba a la mujer como "reflejo invertido de Adán”, un cuerpo más permeable a la corrupción y al pecado. Al hombre le correspondía entonces ejercer control sobre la sexualidad femenina, con el fin de alejarla del mal. La mujer, debía entonces permanecer encerrada, "hacerse cargo del hogar y los hijos, pues al ser susceptible de corrupción podía dañarse en el mundo". ${ }^{37}$

La imagen de los desposorios se situó entonces como expresión del carácter de sujeción y docilidad que debía mantener la mujer frente a su marido. Lo narrado en las pinturas era ratificado no sólo en las Leyes de Indias, donde se obligaba al marido a "cuidar" de su mujer ${ }^{38}$-verbo que comprendía su vigilancia y gobierno-, sino también en la abundante literatura moral que circulaba en aquella época. Obras como la Exemplar vida y muerte dichosa de doña Francisca Zorrilla, escrita por el neogranadino Gabriel Álvarez de Velazco en 1661 dan cuenta de ello. En este texto, uno de los pocos que versa sobre la vida ejemplar de una secular santafereña, se plantea un modelo de lo femenino articulado a partir de principios como la docilidad, el abandono de lo mundano, el encierro y el silencio. Se pretendía que la mujer -en palabras de Velazco- dejara de lado "la mujeril flaqueza para vestirse de ánimo varonil". ${ }^{39}$

\footnotetext{
${ }^{35}$ Biblia de Jerusalén. Génesis, Cap. 4, Vers. 16.

${ }^{36}$ Biblia de Jerusalén, Bilbao: Desclee de Brower. Carta a Timoteo, Cap. 2, Vers, 11-14.

${ }^{37}$ Duby, Historia de la Vida Privada 542.

${ }^{38}$ La legislación hispana trasladada a las Leyes de Indias y basada fundamentalmente en las Partidas de Alfonso X el sabio, señalaban al marido la obligación de gobernar, proteger y alimentar a su mujer. El marido se consideraba responsable ante Dios y las leyes de la salud y la conducta de su mujer, rasgos que derivaban del buen gobierno del marido y la sumisión de la mujer frente al mismo. El hombre debía ser "amoroso y compasivo" así como pacientes con las "flaquezas" femeninas. Así lo señalaba la recopilación de leyes de indias de 1680, como expresión de un contexto dominado por la migración de españoles al Nuevo Mundo que dejaban a sus mujeres en Europa. La normativa buscaba así sostener a la familia como núcleo de colonización, instando a la migración de núcleos familiares y no de hombre solos. Cf. Pereira, Afectos e intimidades 136.

${ }^{39}$ Gabriel Álvarez de Velazco, De la Exemplar vida y muerte dichosa de doña Francisca Zorrilla y Ospina
} 
Sin embargo, cabe señalar aquí que la idea de una pareja dominada por la autoridad del varón frente a la cual se somete la mujer se halla vinculada al ámbito de los discursos y no a los de las prácticas. Para el caso de la América española estudios como los realizados por Kimberly Gauderman han demostrado que el esquema patriarcal en el que la mujer se somete a las órdenes del marido recluyéndose en la esfera del hogar, no representó una práctica común. ${ }^{40}$ Estos hechos nos llevan a sugerir que el discurso inscrito en la pintura de los desposorios representó el ideal social que la Iglesia y la monarquía proyectaron sobre sus dominios, pero no la práctica social predominó en territorios como la Nueva Granada.

Dentro de esta perspectiva el discurso de pareja fomentado por la Iglesia, más allá de la realidad, pretendió establecer una fuerte distancia entre la mujer, sumisa y sometida, y el hombre, cuyo rol se establecía a partir de las ideas de gobierno y mando del hogar, percepciones que iban en consonancia con las ideas de sujeto y sociedad preconizadas por la Iglesia. El discurso visual se convierte aquí en un transmisor más de este discurso patriarcal que ya había impregnado las líneas de los sermones y las obras morales que circulaban en la Nueva Granada. Ejemplo de esto es la alusión que hace al tema del gobierno masculino el moralista neogranadino Juan Bautista del Toro. En su obra del Toro resumirá la idea de familia, expresando el papel que debían cumplir hombres y mujeres:

Mande y govierne el marido; pero ponga mucho cuidado en no pasar al extremo en gobernar y mandar. No formó Dios a la muger de la cabeza de Adán, dize San Agustín; pero ni de los pies la formó. No la formó de la cabeza, por que no era para governadora; ni de los pies quiso formarla, por que no la criaba para esclava. La formo del lado por que la daba a su Esposo para compañera. Dexosela sujeta por eso la saco debajo del brazo; pero muy cerca del corazón. [...] no es marido sino bestia el que a su mujer lastima dice San Juan Chrisostomo. Cierto es que al marido le toca la corrección; pero no ha de andar la temblando como si fuera su esclava. [...] Considerandose cabeza no se detenga solo en el mando, pase al cuidado y trabajo para el sustento y darle a la muger todo lo necesario, sin darle en rostro con el dote que traxo o que no traxo..$^{41}$

La narración ratifica la sumisión de la mujer ante el marido expuesta a través del discurso visual. Sin embargo, advierte que el marido no se debe exceder en el sometimiento de la esposa, pues no es tampoco una esclava. Retórica visual y escrita

\footnotetext{
(Alcalá: Imprenta del Colegio de Santo Tomás, 1661) 126.

${ }^{40}$ Partiendo de los estudios de corte revisionista realizados por Joan Scott en los que se utiliza la categoría de género como principio para la revisión del papel de la mujer en la historia, autores como Kimberly Gaudeman han cuestionado la idea de una sociedad colonial jerarquizada, en la cual el hombre se instituye como la figura central de autoridad. Frente al modelo del poder absoluto del varón (padre o marido) sobre sus hijos y su esposa -análogo a la autoridad del rey-, Gauderman evidencia un rol protagónico, en muchas ocasiones, de la mujer dentro del ámbito colonial. Esto evidencia la brecha existente entre la norma y los discursos emitidos por la Iglesia y el Monarca, y el desarrollo de las prácticas cotidianas en los territorios coloniales. Cf. Joan Wallach Scott, Genero e Historia (México: FCE, 2008) 48-74; y Kimberly Gauderman, Women's lives in colonial Quito. Gender, law and economy in Spanish América (Austin: University Of Texas Press, 2003) 15-27.

${ }^{41}$ Bautista del Toro, El Secular Religioso 249.
} 
se unen aquí para construir un mismo discurso: el matrimonio es un sacramento destinado a la procreación en el cual la mujer debe someterse al hombre y seguir sus leyes para el sostenimiento del hogar.

\section{Una imagen para sacralizar}

El proceso de Conquista y colonización de América coincidió con la explosión de la cultura Barroca, surgida en Europa casi como extensión de la Contrareforma católica. La superposición temporal de ambos procesos permitió que el Segundo -el barroco- se convirtiera en sostén discursivo para la formación de sociedades en el Nuevo Mundo, argamasa que vincularía a cada sujeto con un ideal: el de una vida regida por la norma eclesiástica. El Matrimonio, como base fundamental de la familia, y por ende de la sociedad, no escapó a la influencia del barroco, convirtiéndose en América en una expresión de la teatralidad y el control postridentino. Esa "teatralidad"42 fue precisamente la que quiso reforzar Trento en relación con el sacramento, cuando dispuso que este fuera siempre ejecutado en un templo, en presencia del sacerdote y frente a la sociedad como testigo de la unión que allí se producía. El matrimonio se convertía así en un "hecho visible" y por ende controlable por parte de la Iglesia y la sociedad.

Este control fundamentado a partir de la exposición pública del rito matrimonial se expresaba como una ruptura frente a lo que había sido el sacramento hasta el siglo XVI. Desde la Antigüedad el Matrimonio había consistido en un pacto entre familias, celebrado siempre al amparo de la intimidad propia del hogar. En las casas se prometían los novios, intercambiaban regalos como símbolos del acuerdo y allí mismo -en el hogar- transcurrido un tiempo, se oficiaba la boda. ${ }^{43}$ Aunque a partir del siglo XII la Iglesia buscó dotar al sacramento de un carácter mucho más ceremonial y público, sacándolo de la casa al atrio de la iglesia, la plaza o cualquier lugar concurrido, ${ }^{44}$ lo cierto es que el Matrimonio se mantuvo vinculado a una esfera privada, determinada fundamentalmente por los "esponsales". Desde el siglo XII el matrimonio se había dividido en dos partes: los esponsales y la velación. Mientras la primera se centraba en el acuerdo gestado entre los contrayentes, a lo cual se

\footnotetext{
${ }^{42}$ Cabe señalar que la cultura barroca, amparada en la necesidad de persuadir a la sociedad por medio de la afectación de los sentidos, configuró una retórica dominada por el boato y la exteriorización exagerada de las prácticas colectivas. Las misas, las procesiones, las juras reales, las fiestas y claro, el matrimonio, se convirtieron en un espectáculo dotado -como ha señalado Fernando Rodríguez de la Flor- de una poderosa "dimensión ritualística", la puesta en escena de un poder ejercido de modo teatral cuyo fin último era la subyugación de los sujetos. Cf. Fernando Rodríguez de la Flor, Mundo Simbólico. Poética, política y teúrgia en el barroco hispano (Madrid: Akal, 2012) 253-275.

${ }^{43}$ Gamboa, El precio de un marido 120.

${ }^{44} \mathrm{El}$ "lugar más concurrido" era definido por la iglesia como aquel que se consideraba como el más público: la plaza, el cementerio, o todo aquel espacio donde la comunidad se reuniera. La idea era trasladar el matrimonio desde una esfera privada hasta un espacio público que permitiera que el sacramento matrimonial fuera vigilado y respaldado por toda la sociedad. El papel del sacerdote, limitado en los siglos X y XI a la mera bendición del lecho nupcial, ganará protagonismo en tanto que será él quien aglutinará a la comunidad en torno a la bendición sacramental de la pareja. Véase: Philippe Aries, "El matrimonio indisoluble", Sexualidades occidentales, A. Bejin Philippe Aries y otros (Barcelona: Paidós, 1987) 209-210.
} 
denominaba sponsalia ${ }^{45}$ la segunda consistía en la ceremonia de bendición de la pareja, rito que hacía posible la posterior consumación. ${ }^{46}$

En cuanto a los "esponsales" cabe señalar que estos se celebraban muchas veces con años de antelación a la boda y representaban -al menos en el imaginario de la sociedad- el matrimonio mismo. Para las familias, acostumbradas a buscar acuerdos beneficiosos para su economía o rango social, bastaba con llegar a un arreglo matrimonial ventajoso, así no se bendijera posteriormente la unión. La iglesia quedaba así, en múltiples ocasiones, excluida del pacto matrimonial, práctica que se extendió -con ciertos matices- a lo largo de los siglos XVI, XVII y XVIII. ${ }^{47}$

El carácter plenamente intimista asociado a los esponsales acarreaba una serie de problemas que fueron los que el Concilio de Trento quiso zanjar. Una dificultad fue que la palabra de matrimonio empeñada frente a los padres de la novia muchas veces era incumplida, o lo que era peor, utilizada como fórmula para acceder a los favores sexuales de la doncella. Durante siglos se había considerado que los esponsales -"la palabra empeñada"- podían dar paso al sostenimiento de relaciones sexuales por parte de los prometidos, dando forma así a una especie de "Matrimonio Presunto". ${ }^{48} \mathrm{Sin}$ embargo, en la práctica esto acarreaba un grave riesgo ya que, si el hombre incumplía su palabra sin la mediación eclesiástica, la mujer quedaba relegada a una posición desventajosa. El incumplimiento, convertido en una extendida práctica masculina, fue trasladado a América donde se situó como la causa de largos pleitos, en los cuales la justicia buscaba reparar el honor de las ofendidas mujeres. En el caso de la Nueva Granada fue común que los padres de doncellas burladas se acercaran a los tribunales buscando justicia frente a la palabra incumplida.

Uno de estos casos llevó a Benito de Rocha en 1744 a denunciar a Francisco de la Vega -vecino de la Ciudad de Muzo- por haber tenido "trato" con su hija Jacinta de Rocha, "desflorándola con palabra de casamiento". ${ }^{49}$ El ofendido padre buscaba que Vega cumpliera su palabra o que la "dotare" con algún tipo de retribución económica. ${ }^{50}$ El alcalde decidió, tras un largo proceso, poner preso a Vega e incautar

\footnotetext{
${ }^{45}$ Los Sponsalia fueron definidos originalmente por los romanos, quienes observaron en este procedimiento un pacto "con miras al porvenir". Allí se acordaba la unión y se negociaban acuerdos monetarios o relativos a la entrega de bienes. Los esponsales se convertían en "palabras de futuro", tal como lo entendieron los canonistas medievales que extendieron la tradición hasta los siglos propios de la colonización de América. Cf. Gaudemet, El Matrimonio 43-44.

${ }^{46}$ El nombre de velación derivaba del papel protagónico que tenía el velo de la novia, prenda que en ocasiones cubría a la pareja como símbolo de unión. Véase: Jorge Gamboa, El precio de un marido, 120.

${ }^{47}$ Pereira, Afectos e intimidades 65-66.

${ }^{48}$ Gaudemet, El Matrimonio 199.

${ }^{49}$ Archivo General de la Nación Colombia (AGNC), Sección Colonia, Juicios Criminales, Tomo 171, Fol. 501.

${ }^{50}$ Como ha señalado la historiadora cubana Asunción Lavrin muchos de los litigios iniciados en la América Colonial debido al incumplimiento de la palabra matrimonial demandaban inicialmente que el novio cumpliera, con la doncella y su honor, casándose con ella. Sin embargo, en el transcurso del juicio las mujeres y sus familias se decantaban por la búsqueda de un arreglo económico; una dote que -en palabras de Lavrin- "les permitiría encontrar marido, sin mencionar que era el "precio" por su virginidad perdida".
} 
sus bienes, los cuales, según el alegato del denunciado, no eran suyos sino de su padre, por lo cual se decidió devolverlos a su tenedor. ${ }^{51}$ Mas allá del fallo, el proceso nos habla de una práctica persistente a lo largo del periodo colonial: la de hacer pactos privados en los que la Iglesia no intervenía. Estas componendas abrían la puerta a un galanteo mediado -en muchos casos, como señala Asunción Lavrin- por el inicio de las relaciones sexuales. ${ }^{52}$

La privacidad asociada al rito matrimonial favorecía además el incremento de las relaciones ilícitas y la bigamia. Los hombres, sin dar parte a la iglesia, gestaban pactos con los padres de varias mujeres a la vez, o contraían matrimonios por vía de consumación -acordando con los padres de la mujer y sosteniendo relaciones con ellasin que estos se hicieran públicos, lo que a futuro acarreaba el descubrimiento de otra unión, ya fuera en América o en España. Esta práctica, muy frecuente en los albores de la colonización, dio vida a múltiples querellas en las cuales los peninsulares migrados eran devueltos a España u obligados a traer a sus mujeres. En 1587, por ejemplo, se le abrió juicio a Hernando Alonso Guerrero, vecino de la ciudad de Tunja, por "estar casado en los reynos de España" y estar a punto de contraer un nuevo matrimonio en la ciudad neogranadina. La falta le acarreo a Guerrero presidio en la Cárcel Real de Santafé, y su posterior expulsión del reino..$^{53}$

Frente a todo esto la Iglesia tridentina reaccionó fortaleciendo el carácter público y sacramental del matrimonio, subrayando de paso el papel protagónico del clero como rector del sacramento. La imagen de los Desposorios de la Virgen y san José funcionó en este sentido como vehículo de promoción de dicha postura. El discurso visual que, como hemos visto, sirvió para controlar la sexualidad y determinar los roles que debían cumplir los integrantes de la pareja, permitió también manifestar, a partir de la iconografía, la renovación de una práctica matrimonial pública y teatral, que invalidaba toda unión al margen del control eclesiástico.

¿Cómo lograron esto? Observemos un nuevo ejemplo. En los Desposorios de la Virgen y San José atribuidos a Baltasar Vargas de Figueroa (Imagen 3) se hace evidente que el pintor escogió como centro de la representación la escena central, eliminando el decorado y los personajes laterales observables en las imágenes 1 y 2 ya analizadas. La elección de Vargas de Figueroa constituye como actor principal al sacerdote, quien imponiendo sus manos sobre la de los contrayentes, avala la unión.

\footnotetext{
Véase: Asunción Lavrin, "La sexualidad en el México Colonial: un dilema para la Iglesia". Sexualidad y matrimonio en la América hispánica. Siglos XVI-XVIII, coord. Asunción Lavrin (México: Grijalbo, 1991) 73 .

${ }^{51}$ AGNC, Sección Colonia, Juicios Criminales, Tomo 171. Fol. 501v-505v.

${ }^{52}$ Asunción Lavrin sostiene que las relaciones sexuales de la pareja se iniciaban normalmente en la etapa del noviazgo, forzadas casi siempre por el hombre, amparado en la palabra matrimonial dada o en una promesa de la misma. En algunos casos si la mujer accedía a tener relaciones el hombre luego evadía su responsabilidad, exponiendo como argumento ante los tribunales la poca reputación de una mujer que accedía a tener relaciones sin hallarse casada, exponiéndola como una pecadora "mujer de mundo". Véase: Lavrin, La sexualidad en el México Colonial 69.

${ }^{53}$ AGNC, Sección Colonia, Juicios Criminales, Tomo 103. Fol. 943-944.
} 
La escogencia tiene un valor primordial dentro de la narrativa de la escena, pues indica al espectador el papel central de la Iglesia dentro del acto matrimonial. La pintura estaba destinada a comunicar el poder de la Iglesia dentro de la sociedad colonial, así como todo aquello que derivaba del hecho de que la unión fuera pública y bendecida por Dios.

Imagen 3: Desposorios de la Virgen y San José Baltasar Vargas de Figueroa (Atribuido), siglo XVII.

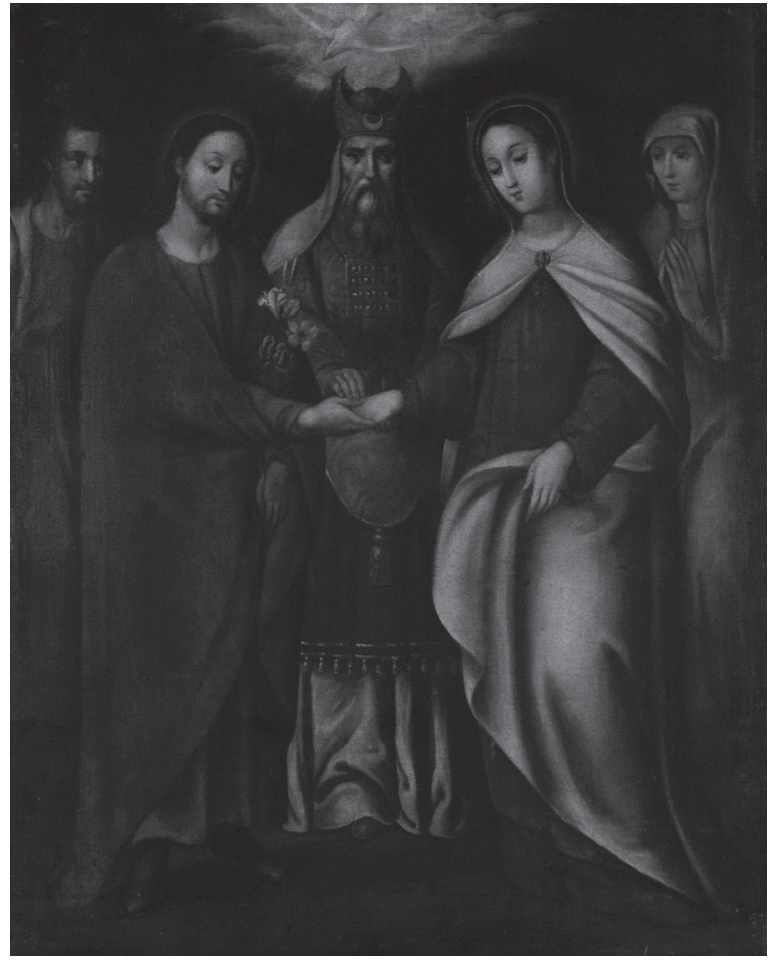

Fuente: Colección Museo Santa Clara (Bogotá)

El sacerdote se convierte dentro de la pintura en el elemento legitimador de la unión, mientas que los acompañantes laterales -ubicados al lado de la virgen y san José- afirman su carácter público. Cabe señalar que el ceremonial matrimonial que se representa en la pintura es el que se celebraba dentro del rito judío, ${ }^{54}$ razón por la

\footnotetext{
${ }^{54}$ El rito matrimonial judío, al igual que el rito católico, se dividía en dos partes: los esponsales y las nupcias. Mientras los esponsales se basaban en el acuerdo con el futuro esposo -establecido en el caso de José con el florecimiento de su cayado-, las nupcias o nissu'in contaban con varios rituales asociados. La futura esposa debía purificarse en un baño ritual denominado miqwaoth, donde era purificada y vestida por las mujeres del lugar. Terminado este rito la novia, acompañada por diez mujeres -esas que aparecen acompañando a la Virgen en la pintura- esperaba en su morada al futuro esposo. Este, acompañado por los hombres de su tribu que le servían de testigos, recibía allí la bendición impartida por el sacerdote del templo. Este, siempre un anciano, encabezaba luego la procesión de la pareja que salía de la casa de la novia hacia el nuevo hogar, acompañados siempre por la luz de las antorchas que llevaban los acompañantes, símbolos del pacto hecho por Yahve y Abraham, restablecido con la alianza matrimonial de la nueva pareja. Véase: Juan Luis Bastero, Vida de María (Madrid: Rialp, 2014) 125-126.
} 
cual quien aparece como protagonista es un Sumo Sacerdote del Templo, tocado con la mitra del culto hebreo. La fórmula iconográfica se basaba fundamentalmente en los grabados de Alberto Durero reproducidos luego a gran escala. El uso del grabado, indiscutible en el caso de esta escena, permitió al pintor dar forma a una sencilla imagen cuya finalidad última era la de llevar a los fieles de la Nueva Granada el mensaje de la Iglesia Tridentina.

En el caso del matrimonio, lo comunicado a través del discurso visual se ajustaba a lo dictaminado por el concilio en las sesiones celebradas entre marzo y mayo de 1547. Los largos debates acometidos por numerosos teólogos condujeron a dos conclusiones: la primera reafirmaba el carácter sacramental del matrimonio, así como la potestad única e incuestionable de la Iglesia sobre su administración. La segunda -derivada en parte de la primera- era la necesidad de dotar al Matrimonio de un rito religioso, en tanto que era un componente sagrado, una parte constitutiva de la unión de Cristo con su Iglesia. ${ }^{55}$ A partir de esta premisa Trento exigió -mediante el decreto Tametsi- ${ }^{56}$ que los matrimonios se celebraran únicamente en el interior de las iglesias y delante del párroco, so pena de nulidad matrimonial y dado el caso excomunión. ${ }^{57}$ El rito, celebrado dentro del templo, permitiría vigilar las uniones desde su gestación, haciéndolas públicas, poniendo freno así a los vínculos clandestinos o no consensuados. La preocupación de la Iglesia frente a problemas como estos se hallaba vinculada al hecho de que afectaban la base misma de la estructura social cristiana que buscaban edificar.

La norma Tridentina, trasladada al contexto de una Nueva Granada cuya sociedad se hallaba aun en gestación, se convertirá en pilar fundamental de ese nuevo mundo. El matrimonio era considerado la piedra angular de la familia, entendida a su vez como célula de la sociedad. Controlar la unión matrimonial, aseguraba entonces el control de toda la cadena constitutiva del entramado social. La aparición de los “desposorios" en la Nueva Granada -así como en los virreinatos del Perú o La Nueva España- como una iconografía recurrente, da cuenta de la necesidad que tuvo la iglesia de dejar en claro los parámetros que regían la cohabitación de hombres y mujeres, más aún dentro de una sociedad tan heterogéneas como la neogranadina. La imagen se convertía así en la emisora de un decreto de cuyo acatamiento dependía no sólo el andamiaje social, sino también el proyecto trazado por la Iglesia para la Nueva Granada.

Para que esto se llevara a cabo era necesario un mecanismo de divulgación permitiera que -como señala asunción Lavrín- "la gente común entendiera mejor sus enseñanzas sobre la naturaleza y el objetivo de las relaciones entre hombres y

\footnotetext{
${ }^{55}$ Gaudemet, El Matrimonio 259.

${ }^{56}$ El decreto Tametsi fue firmado el 11 de noviembre de 1563 durante la XXIV sesión del Concilio de Trento y constituye el primero de los diez capítulos componen el decreto general tridentino sobre el matrimonio titulado: De reformatione matrimonii. El decreto exige, fundamentalmente, la celebración del matrimonio en la iglesia y ante el párroco, so pena de nulidad. El decreto estuvo vigente hasta 1917, cuando el papa Benedicto XV promulgó un nuevo código de Derecho Canónico. Véase: Gaudemet, El Matrimonio 343.

${ }^{57}$ Gaudemet, El Matrimonio 343.
} 
mujeres". ${ }^{58}$ Este trabajo recaía sobre los sacerdotes quienes debían hallar los mejores canales de difusión para que el mensaje llegara a la feligresía, de aquí la importancia del uso de iconografías como los "desposorios". La imagen permitió definir una estructura matrimonial para la Nueva Granada cuya base era el control, manifestado visualmente a partir del argumento iconográfico, y materializado en la complejidad burocrática asociada al sacramento.

Cabe señalar aquí que, siguiendo los dispuesto en Trento, para que el rito matrimonial pudiera ser celebrado, los contrayentes debían primero presentarse ante el cura y elevar su petición. A esto seguía la apertura de una "causa" en la que a partir de múltiples testigos se examinaba a los contrayentes, así como la posible existencia de causales que impidieran la unión. Un ejemplo de este proceso lo tenemos en el Matrimonio de Pedro de Ayala y Leonor Rodríguez celebrado en el pueblo de Pasca. El 16 de febrero de 1692 se abrió un memorial para recoger los testimonios de amigos y vecinos que legitimaran en primera instancia la unión. La revisión pública del matrimonio, dispuesta por Trento y representada en la iconografía de los desposorios, se materializaba en las declaraciones de los testigos, quienes jurando por Dios y haciendo "la señal de la santa cruz", respondían a cuestiones relativas al reconocimiento de la pareja, y al discernimiento de aspectos como la existencia de matrimonios anteriores, de promesas de matrimonio a otras mujeres, de parentesco o vínculos de consanguinidad entre la pareja, o de impedimentos para consagrar la unión. A esto se sumaban las cuestiones relativas a la libertad con que habían elegido casarse, aspecto que permitía dilucidar si la mujer se hallaba forzada a contraer nupcias. ${ }^{59}$

El cuestionario se centraba en los impedimentos matrimoniales, buscando a su vez alertar a la población sobre el matrimonio, con el fin de que quien supiera algo oculto, lo revelara ante las autoridades eclesiásticas. Finalmente, si la pareja cumplía con todos los requisitos, la boda se celebraba, siguiendo el rito público contrareformista. La unión sacramental se convertía así en un nuevo teatro observado por todos $\mathrm{y}$, por ende, vigilado por todos. Pero para que dicha vigilancia se cumpliera era necesario que, en paralelo al uso de la imagen, los sacerdotes estuvieran al pendiente de su feligresía, repitiendo mediante el sermón las disposiciones matrimoniales y los castigos que acarreaba su incumplimiento. La sociedad, articulada como cuerpo social, volvía a actuar aquí -al igual que en el tema de la sexualidad-como panóptico, entramado delator en el que cada uno tenía como misión vigilar al otro.

Finalmente, la imagen de los Desposorios de la Virgen sirvió para transmitir un mensaje. Este, ya fuera para evidenciar las disposiciones tridentinas relativas al rito matrimonial, al control de la sexualidad, o al papel que debía desempeñar cada sujeto dentro de la pareja, tuvo como directriz la de establecer límites a una sociedad en crecimiento. Lo dispuesto en el Concilio de Trento encontró entonces como canal de comunicación a la imagen, recurso que permitiría unir a las dos orillas atlánticas

\footnotetext{
${ }^{58}$ Lavrin, La sexualidad en el México Colonial 57.

${ }^{59}$ AGNC, Sección Colonia, Fondo Miscelánea, Tomo 133, fols. 151r-152r.
} 
bajo un mismo paradigma, un discurso que, si bien no se materializó completamente, sí dejó una huella dentro de la cultura colonial de los siglos XVII y XVIII. Este carácter de huella es el que encontramos dentro de la iconografía de los "desposorios", materialización visual de ese discurso tridentino que dio vida, también en la Nueva Granada, a una cultura que bien podemos designar como barroca.

\section{A modo de conclusión: una imagen entre el discurso y la práctica}

Siguiendo a Michel Foucault "el siglo XVII sería el comienzo de una edad de represión". ${ }^{60}$ La Iglesia, como respuesta al avance protestante, cerrará filas en esa centuria, imponiendo reglas y modelos a los sujetos bajo la premisa quimérica de dar forma a una sociedad cristiana, respetuosa de la Iglesia y del monarca. Estas ideas, cocinadas en una Europa dominada por la crisis social y el decaimiento de los poderes regios y eclesiásticos, darán forma a la cultura barroca, estratagema retórica y visual dirigida a recobrar ese poder perdido. Trasladada a América y materializada en imágenes, sermones y obras morales, esa cultura barroca o pos-tridentina, pretenderá dar forma a las nuevas sociedades, amparándose en esa "represión" mencionada por Foucault, la cual buscará por todos los medios disciplinar el cuerpo y las actitudes de los sujetos.

Precisamente es esa regulación social propia del barroco la que se hace presente en la iconografía de los Desposorios de la Virgen y San José desarrollada en la Nueva Granada del siglo XVII. Como hemos evidenciado en las páginas precedentes, la imagen del matrimonio de María y San José permitió llevar a los fieles unas formas de comportamiento, unas reglas dirigidas no solo a prevenir las uniones ilícitas, sino también a controlar la sexualidad y establecer unos roles a cumplir por parte de los integrantes de la sociedad. Las imágenes, diseminadas en templos, conventos y oratorios privados, canalizaron discursos y permitieron a la Iglesia comunicar a los fieles de forma didáctica esas características que debían ser inmanentes al sujeto colonial. Una mujer sometida, casta, respetuosa de su marido se erigía como modelo a partir de la pintura del siglo XVII. En paralelo esa misma iconografía trazaba la imagen de un hombre casto que debía gobernar y proteger a su mujer.

Como paradigmas del “deber ser", estos ideales, impuestos a través del miedo esgrimido como fórmula de convencimiento, suponían la configuración de sociedades controladas por el discurso, así como por los entes que lo emitían. Sin embargo, aunque la imagen, los sermones y las obras morales predicaron siempre un modelo de sujeto, la sociedad y sus prácticas se encargaron de pervertirlo. El matrimonio es también en este caso una muestra de ello. Aunque las imágenes de los Desposorios desarrolladas en la Nueva Granada nos dan cuenta clara del modelo patriarcal y de sometimiento sexual tridentino, la realidad nos presenta otra cara. Uxoricidios, amancebamientos, fugas de amor y matrimonios ilícitos, entre otros problemas, componían el menú diario de los tribunales neogranadinos en el siglo XVII. La presencia de estos problemas

${ }^{60}$ Michel Foucault, Historia de la Sexualidad, Tomo 1: “La Voluntad del Ser” (Madrid: Siglo XXI, 2012) 18. 
demuestra que discurso y práctica no van siempre de la mano, y que en muchos casos es el mismo control el que incita la subversión.

Esa complejidad derivada de la tensión entre norma y práctica queda retratada en casos como el vivido por Bárbara y Salvador López, una pareja avecindada en Santafé de Bogotá en los albores del siglo XVII. En noviembre de 1612 Bárbara López se presentó a los tribunales para "querellarse contra su marido", -un oficial de zapatero de treinta años- acusándolo de haberla golpeado produciéndole heridas en la cabeza. Según la declaración ofrecida por la señora López, su esposo "le dio muchos palos en la cabeza de los cuales le hizo dos heridas en la cabeza de que le corto cuero y carne y le salio mucha sangre". La razón para tal conducta era que la señora Bárbara le había pedido que "no estuviese amancebado y hiziese vida con ella como su mujer que era". ${ }^{11}$ Aquí la señora López, sustentándose en los deberes maritales expresados como norma por la Iglesia y la ley, recrimina al marido por algo que claramente está mal hallarse amancebado, aspecto seguido por otra conducta reprobable, golpearla sin razón. Leído a la luz de lo expresado por la pintura de los desposorios este era un caso resuelto. El marido había obrado mal y por ello el licenciado Alonso Vásquez de Cisneros -quien llevaba la causa- dictaminó que salvador López fuera encarcelado.

Sin embargo, en medio del presidio, el supuesto agresor dio su versión de lo ocurrido. Según Salvador López el día de los hechos

\begin{abstract}
hallo a la dicha Bárbara Lopez su muger con otros yndios holgándose y este confesante le dixo que dejase la dicha juerga y se fuesen a su casa pues ya era hora y la susodicha le respondió que no quería sino el holgarse y este confesante que se quedase y el se iría también a holgar y sobre esto este confesante y la dicha su mujer tuvieron palabras de las quales resultó el darle este confesante un empujon con el cual cayo en el suelo y del se levantó descalabrada y que esto que ha dicho es la verdad. ${ }^{62}$
\end{abstract}

El argumento utilizado por el demandado se basaba -al igual que el empleado por su esposa- en la normativa matrimonial señalada por la Iglesia y la ley. Salvador López señaló que era su esposa la que estaba holgándose y en juerga con unos indios, lo cual lo facultó para reprenderla y señalarle que, de no respetar el matrimonio, respondería con la misma actitud. En este caso lo relatado por el acusado se atiene a la norma expuesta por los desposorios en la que se subraya la virginidad de la mujer y su sometimiento frente al varón. El discurso es entonces utilizado no sólo como mecanismo de defensa, sino también como camino para subvertir la norma misma.

La iconografía de los Desposorios de la Virgen y San José transmitirá por lo tanto un discurso dirigido a forjar un tipo específico de sujeto colonial, así como un modelo de pareja y de familia colonial para la Nueva Granada del siglo XVII. El arquetipo terminará incorporándose -y no direccionando, como se pretendía- a la realidad, sirviendo como argumento en medio de los encuentros y desencuentros de

\footnotetext{
${ }^{61}$ AGNC, Sección Colonia. Fondo Caciques e Indios, Tomo 64. F.383

${ }^{62}$ AGNC, Sección Colonia. Fondo Caciques e Indios, Tomo 64. F. 387v
} 
Imágenes para sacralizar, controlar y someter. La pintura y el discurso matrimonial...

la sociedad. Discurso y práctica establecerán así una tensión que funcionará como motor de la colectividad, haciendo emerger a un sujeto producto tanto de la norma -la "represión" a la que alude Foucault-, como de la inobservancia de esta.

\section{Bibliografía}

\section{Fuentes Primarias}

\section{Fuentes de archivo:}

Archivo General de la Nación Colombia (AGNC), Fondo Caciques e Indios, Sección Colonia.

Archivo General de la Nación Colombia (AGNC), Fondo Juicios Criminales, Sección Colonia.

Archivo General de la Nación Colombia (AGNC), Fondo Miscelánea, Sección Colonia.

\section{Libros:}

Carducho, Vicente. Diálogos de la Pintura. Su Defensa, Origen, esencia, definición, modos y diferencias. (1ed. 1633). Madrid: Turner, 1979.

De Villegas, Alonso. Flos Sanctorum y Historia General en que se escribe la vida de la Virgen Sacratissima madre de Dios y Señora nuestra y la de los santos antiguos que fueron antes de la venida de nuestro Salvador al Mundo. Barcelona: Imprenta de Pablo Nadal y Pedro Escuder, 1748.

Novísima recopilación de las Leyes de España, mandada formar por el señor don Carlos IV. Tomo I, Libro 1, Madrid: S.e. 1805.

Pérez, Miguel. La vida y excelencias y Miraglos (Sic) de la Sacratissima Virgen María nuestra señora. Sevilla: Imprenta de Juan Varela de Salamanca, 1525.

Toro, Juan Bautista del. El Secular Religioso, (1 ${ }^{\mathrm{a}}$. Ed. 1712), Madrid: Imprenta de Francisco del Hierro, 1721.

\section{Fuentes Secundarias}

\section{Libros}

Alcalá, Luisa Elena y Jonathan Brown eds. Pintura en Hispanoamérica 1550-1820. Madrid: Ediciones el Viso-Fondo Cultural Banamex, 2014.

Aries, Philippe. El Niño y la vida familiar en el antiguo régimen. Madrid: Taurus, 1982. 
Baschet, Jerome. La civilización feudal. Europa del año mil a la colonización de América. México: FCE, 2009.

Bastero, Juan Luis. Vida de María. Madrid: Rialp, 2014.

Casey, James. Historia de la Familia. Madrid: Espasa Calpe, 1990.

Gamboa, Jorge. El precio de un marido. El significado de la dote matrimonial en el Nuevo Reino de Granada. Pamplona. 1570-1650. Bogotá: ICANH, 2003.

Gaudemet, Jean. El matrimonio en Occidente. Madrid: Taurus, 1993.

Markale, Jean. El amor cortés o la pareja infernal. Barcelona: Medievalia, 1998.

Mujica Pinilla, Ramón. La imagen transgredida. Ensayos de iconografía peruana y sus politicas de representación simbólica. Lima: Fondo Editorial del Congreso del Perú, 2016.

Pastor, Marialba. Cuerpos Sociales, Cuerpos Sacrificiales. México: FCE, 2004.

Pereira Larraín, Teresa. Afectos e Intimidades. El mundo familiar en los siglos XVII, XVIII y XIX. Santiago de Chile: Universidad Católica de Chile, 2007.

Pérez, María Cristina. Circulación y apropiación de imágenes religiosas en el Nuevo Reino de Granada, siglos XVI-XVIII. Bogotá: Uniandes, 2016.

Rodríguez de la Flor, Fernando. Mundo Simbólico. Poética, politica y teúrgia en el barroco hispano. Madrid: Akal, 2012.

Rodríguez Jiménez, Pablo. Sentimientos y vida familiar en el Nuevo Reino de Granada siglo XVIII. Bogotá: Ariel, 1997.

Rodríguez Jiménez, Pablo. ed. La familia en Iberoamérica: 1550-1980. Bogotá: Convenio Andrés Bello, 2004.

Rodríguez Nobrega, Janeth. Las imágenes expurgadas. Censura del arte religioso en el periodo colonial. León: Universidad de León, 2008.

Santos Otero, Aurelio de. Los Evangelios Apócrifos. Madrid: Biblioteca de Autores Cristianos, 1956.

Schenone, Hector. Iconografía del Arte Colonial: Santa María. Buenos Aires: Universidad Católica Argentina, 2008.

Vargas Lugo, Elisa y José Guadalupe Victoria, eds. Juan Correa, su vida y su obra. Repertorio Pictórico, Tomo IV. México: UNAM, 1994. 
Imágenes para sacralizar, controlar y someter. La pintura y el discurso matrimonial...

\section{Capítulos de libros}

Aries, Philippe. "El matrimonio indisoluble". Sexualidades occidentales. Philippe Aries, A. Bejin y otros. Barcelona: Paidós, 1987. 189-214.

Burgiere, André. "El impacto de la Modernidad". Historia de la Familia, Vol. II. Madrid: Alianza, 1988.

Foucault, Michel. "La Voluntad del Ser". Historia de la Sexualidad, Tomo 1. Madrid: Siglo XXI, 2012.

Lavrin, Asunción. "La sexualidad en el México Colonial: un dilema para la Iglesia". Sexualidad y matrimonio en la América hispánica. Siglos XVI-XVIII. Asunción Lavrin, Coord. México: Grijalbo, 1991. 55-104.

Vincent, Bernard y James Casaey, "Casa y familia en la Granada del Antiguo Régimen”. La Familia en España Mediterránea: Siglos XV-XIX. Coord. Pierre Vilar Barcelona: Crítica, 1987. 172- 211.

\section{Artículos de revistas}

Adorno, Rolena. "El sujeto colonial y la construcción cultural de la alteridad". Revista de Crítica literaria latinoamericana 28 (1988): 55-68.

Adorno, Rolena. "The dipiction of self and other in Colonial Perú". Art Journal 49. 2 (1990): 110-117.

Castañeda, Felipe. “¿Cómo pensar la libertad a finales del siglo XI? El caso de Anselmo de Canterbury". Historia Crítica 18 (1999): 101-117.

Schwartz, Stuart B. "Pecar en las colonias. Mentalidades populares, Inquisición y actitudes hacia la fornicación simple en España, Portugal y las colonias americanas". Cuadernos de Historia Moderna 18: (1997): 51-68.

Valenzuela, Eduardo. "Kerigma: preguntas teóricas en torno a la primera evangelización de América (Antillas, 1510-Nueva España 1524)". Historia Crítica 58 (2015): 13-32. 